I'd never known they knew.

Otherwise, silence

except for the breeze through the firs.

\title{
5. Concerto for the Left Hand Alone
}

with the right in a sling - from what?

a great day's work and play, toting a bale

of wallboard, bailing-no, swamping and upending

the rowboat, playing whiffleball in two feet

of water, home runs floating a hundred feet

out on the lake, feet stubbed and scraped on the rocks

under second (a boat cushion floating, tied to a rock),

rowing halfway back from Willow when the outboard

ran out of gas - at last, a mere awkward

twist of the wrist sitting down to be polite

to a friend's father (how strange to have a father

alive when you're forty!)

I remember Ravel's Concerto for the Left Hand,

the heavy bass dances, the light-fingered far-away treble ripples written for a pianist who gave his right to the War, and try to think of all the right hands severed in war or peace, flying off like a flock going south, and the thirty or forty years thereafter

of single- and left-handed flight. . . .

\section{LITERARY ANECDOTE (APOCRYPHAL)}

When bold Elizabeth Bishop found

Her way to St. Elizabeth's,

She heard the prophet Ezra pound

The filthy air with one clean hand.

$\mathrm{He}$ beat the windows with his breaths

Like some big Persian-rug-winged moth. 
And then they danced, a one-two-three,

One-two. She showed him how to do

The Samba, nor had she forgot

Her native style: they did a fox-

trot too. He taught her how to box

Like Hemingway, who'd said her Fish

Was so well caught it made him wish

He'd caught one just as well.

Well, hell,

This anecdote now here first printed

Is totally undocumented. ${ }^{*}$

" But cf. her "Visits to St. Elizabeths" and Ian Hamilton's Robert Lowell , p. 130. The Hemingway statement is found in a footnote in John F. Nims, Harper Anthology of Poetry, p. 652. 